Revue Gouvernance

Governance Review

\title{
The Museum Community and Community Museum Governance
}

\section{Robin Nelson}

Volume 17, numéro 1, 2020

Varia

URI : https://id.erudit.org/iderudit/1070342ar

DOI : https://doi.org/10.7202/1070342ar

Aller au sommaire du numéro

Éditeur(s)

Centre d'études en gouvernance de l'Université d'Ottawa

ISSN

1912-0362 (numérique)

Découvrir la revue

Citer cet article

Nelson, R. (2020). The Museum Community and

Community Museum Governance. Revue Gouvernance / Governance Review, 17(1), 45-66. https://doi.org/10.7202/1070342ar
Résumé de l'article

L'Ontario compte plus de 500 musées de types, de tailles et de besoins différents. Ils ont des relations différentes à la fois avec les politiques gouvernementales et avec les associations qui les représentent. Cependant, la recherche sur la gouvernance des musées se concentre souvent sur les problèmes des organisations provinciales ou nationales, en négligeant les musées communautaires, c'est-à-dire les petites institutions ayant des racines locales ou régionales. En raison de leurs ressources limitées, les musées communautaires comptent sur le travail des porte-parole pour défendre leurs intérêts. Dans la gouvernance des musées de l'Ontario, ces porte-parole utilisent le terme " communauté muséale » pour indiquer un consensus sur une ligne de conduite. Selon une perspective sociologique de la traduction, lorsqu'un porte-parole parle au nom des autres, il doit d'abord faire taire ceux au nom desquels il parle. Cette recherche examine la manière dont les dirigeants du secteur construisent la " communauté muséale » en tant qu'acteur en soutien d'une action particulière, en s'intéressant à qui et quoi forme la communauté muséale et quelles voix ont une tribune en tant que conseillers de musée et associations représentant la soi-disant communauté. L'article conclut que les musées municipaux ont toujours occupé une place privilégiée dans l'articulation de la communauté par les associations de musées, tandis que les conseillers des musées provinciaux ont mieux réussi à faire entendre la voix des petits musées consacrés à la société historique. Alors que les ressources du conseiller en musée sont de plus en plus limitées, l'Association des musées de l'Ontario (OMA) joue un rôle plus actif dans la formation de ces voix. Cependant, l'association dispose de ressources financières limitées. À ce titre, il existe toujours une stratification des musées dans la gouvernance des musées. 


\title{
The Museum Community and Community Museum Governance
}

By Robin Nelson ${ }^{1}$

\begin{abstract}
Ontario has more than 500 museums, varying in type, size, and expressed need. They have different relationships to both government policy and the associations that represent them. Yet, research on museum governance often focuses on provincial or national organizations, neglecting community museums (i.e., smaller institutions with local or regional roots). Due to their limited resources, community museums rely on the work of spokespeople to advocate for their interests. Within Ontario museum governance, these spokespeople use the term "museum community" to indicate consensus on a course of action. According to a sociology of translation perspective, when a spokesperson speaks for others, they must first silence those in whose name they speak. As such, this paper considers how those governing the sector construct the "museum community" as actors in support of particular action. It asks who and what forms the museum community? Which voices are given a platform as museum advisors and which associations represent the so-called community? The paper concludes that municipal museums have historically had a privileged position within museum associations' articulation of community, while provincial museum advisors have more successfully included the voices of small historical society museums. As the museum advisor's resources have become more limited, the Ontario Museum Association (OMA) has taken a more active role in assembling those voices. However, the association has limited financial resources. As such, there continues to be a stratification of museums in museum governance.
\end{abstract}

Keywords: community museums, sociology of translation, cultural policy

\section{RÉSUMÉ}

L'Ontario compte plus de 500 musées de types, de tailles et de besoins différents. Ils ont des relations différentes à la fois avec les politiques gouvernementales et avec les associations qui les représentent. Cependant, la recherche sur la gouvernance des musées se concentre souvent sur les problèmes des organisations provinciales ou nationales, en négligeant les musées communautaires, c'est-à-dire les petites institutions ayant des racines locales ou régionales. En raison de leurs ressources limitées, les musées communautaires comptent sur le travail des porte-parole pour défendre leurs intérêts. Dans la gouvernance des musées de l'Ontario, ces porte-parole utilisent le terme «communauté muséale» pour indiquer un consensus sur une ligne de conduite. Selon une perspective sociologique de la traduction, lorsqu'un porte-parole parle au nom des autres, il doit d'abord faire taire ceux

1. Robin Nelson is a doctoral candidate in Public Administration at the University of Ottawa 
au nom desquels il parle. Cette recherche examine la manière dont les dirigeants du secteur construisent la «communauté muséale » en tant qu'acteur en soutien d'une action particulière, en s'intéressant à qui et quoi forme la communauté muséale et quelles voix ont une tribune en tant que conseillers de musée et associations représentant la soi-disant communauté. L'article conclut que les musées municipaux ont toujours occupé une place privilégiée dans l'articulation de la communauté par les associations de musées, tandis que les conseillers des musées provinciaux ont mieux réussi à faire entendre la voix des petits musées consacrés à la société historique. Alors que les ressources du conseiller en musée sont de plus en plus limitées, l'Association des musées de l'Ontario (OMA) joue un rôle plus actif dans la formation de ces voix. Cependant, l'association dispose de ressources financières limitées. À ce titre, il existe toujours une stratification des musées dans la gouvernance des musées.

Mots-clés: musées communautaires, sociologie de la traduction, politique Culturelle

\section{Introduction}

Policy translation is a governance perspective whereby governance results from the co-production of many actors (Clarke, 2012). Studying policy translation involves studying governance practices, which are relational assemblages of elements, resources, and capacities assembled in a certain way for particular interests and purposes (McCann \& Ward, 2013). Within this perspective, museum governance entails the relationships mobilized in the work of museums, including relationships between museums, government actors, museum associations, and policy instruments.

Literature documenting the relationships governing museums is primarily concerned with issues pertaining to large national institutions (e.g., Greffe, 2011; Jaffry \& Apostolakis, 2011; Nisbett, 2013; Paquette, 2010), with the notable exception of work on local authority museums in the United Kingdom (e.g., Gray, 2015; McCall, 2009; Poulard, 2012; Stylianou-Lambert, Boukas, \& Christodoulou-Yerali, 2014). As most museums are smaller institutions with local or regional roots-that is, community museums - research has focused on the issues of a relatively small population of organizations. For instance, in Canada, there are more than 2,600 museums, public art galleries, and related heritage institutions (Canadian Museum Association [CMA], 2016). There is also a limiting divide in research between an American tradition, which emphasizes board governance and fundraising in private or not-for-profit institutions (e.g., Jung, 2015; Weil, 1997), as well as a European and Canadian tradition, which discusses the challenges of state institutions with regards to their public service missions (e.g., Ashley, 2014; Bandelli \& Konijn, 2015). The second tradition emphasizes the hardships that museums face due to tightened public finances and changing public 
discourses. However, scholarship rarely engages with the governance of Canadian community museums. These institutions face a distinct set of challenges related to public support.

Community museums in Canada navigate policies relevant to their operating authority, including municipalities, conservation authorities, nonprofit organizations, and Indian band councils. Despite differences in these organizational structures, policies targeting community museums are aimed at a sectoral level and not tailor-fit to a single institution type. All levels of government can have policies targeting community museums as culture is not the designated responsibility of any one level of government; this results in multi-level governance. These policies have also enabled a range of nonprofits organizations that support community museums, such as the Canadian Museum Association.

In Ontario, provincial museum advisors and associations do the work of governing community museums. The Ontario Historical Society (OHS), a non-profit association that works to preserve Ontario's heritage, formed a museum committee in 1953 for the betterment of Ontario museums. To that end, the OHS provided training, circulated information, and incorporated non-profit museums or related entities. The province also began offering an operating grant to community museums in 1953. In order to process these grants, Ontario has employed one or more provincial museum advisors since 1959. These advisors are museum professionals who also provide technical advice and assistance to community museums. In 1972, museum workers formed the Ontario Museum Association (OMA) as a nonprofit dedicated exclusively to museums. Their main objective was to improve the standards of museum operation in Ontario through training, the circulation of information, and advocating to government. The province provides both the OHS and OMA annual operating grants to help create a strong and stable cultural sector. In assembling and enacting support for museums, the OHS, museum advisors, and OMA have served as spokespeople for the "Ontario museum community."

The "Ontario museum community" is a term that actors (re)define differently depending on the context. While the meaning of museum is contested, the museum community refers to institutions that self-identify as museums and their associated entities, including volunteers and staff (Ontario Museum Association [OMA], 2000). The museum community is distinct from the museum public, who lack knowledge related to museum operations and needs. The term obscures diversity, providing a punctuated actor-that is, an entire network converted into a single point for which spokespeople can act (Callon, 1991). As a punctuated actor, the museum community can represent and convey feelings, opinions, and a historical narrative. Despite the homogeneity of this so-called museum community, Ontario has more than 500 museums, varying in type, size, and expressed need. Considering this diversity, the paper looks at how those 
governing the sector construct the "museum community" as an actor in support of particular actions. More precisely, who and what forms the museum community? Which voices are given a platform as museum advisors and associations speak for the so-called community?

To begin, I discuss the sociology of translation, focusing on its contribution to understanding power relations in governance. Studying processes of translation enables a consideration of how relationships are negotiated, and voices are silenced to achieve consensus. After outlining my research approach, I describe actors' work to (re)define the museum community and its governance in three time periods. These periods can be framed by (1) the establishment of governing institutions; (2) increased advocacy; and (3) the reduced role for government. The discussion examines power dynamics by considering a stratification of community museums and the risks involved in relying on an association for governance. This builds to the conclusion that the way actors construct the museum community helps explain why and how museum services in Ontario have developed to favour certain museums over others.

\section{Conceptual Framework}

The sociology of translation (Callon, 1986a, 1986b) provides a lens to better understand the relationships involved in the enactment and mobilization of a museum community, studying the processes through which actors become connected (Zapata Campos \& Zapata, 2013). Actors negotiate they identities, the possibility of interaction, and the margins of manoeuvre during translation. Translation provides consensus on a definition of rules and roles for an actor network - that is, something made to act and exist through its relationships (Latour, 2005). Community museum governance is an actor network, involving those relationships mobilized to support and regulate museums.

Once translated, a spokesperson can speak for an actor network in their own language, effectively silencing those in whose name they speak (Callon, 1986a). Within this framework, power is relational and an effect of collective action (Parsons, 1999). Power resides in delegation as allies join forces, attributing their action to a spokesperson, as well as discipline whereby delegates are convinced to conform to particular patterns of action and representation. Power involves a metaphor that brings actors together and holds them there (Leigh Star, 1990). As such, the dispersed and diverse power relationships of museum governance can be understood through research on how actors are defined, associated, and compelled to remain faithful to alliances (Callon, 1986b). 
Some actors have greater capacity to both firmly associate a large number of elements and disassociate elements that other actors enroll (Law, 1992). In particular, complex actor networks, such as a level of government or museum association, can be "blackboxed," becoming firmly established with certain practices in a stable hierarchy with relationships that are no longer considered (Rice, 2011). They are then punctualized as a single node within other actor networks, which can then be further punctualized as needs dictate. The actors speaking for punctualized actor networks have greater capacity to translate entities and maintain that translation due to the strength of the relationships on which they rely (Callon \& Latour, 1981). As such, the punctuated voice of museums-i.e., the museum community-has greater capacity to translate museum governance than an individual museum, and there will be actors with greater capacity to translate a museum community.

Within Ontario museum governance, the museum community is a metaphor that spokespeople use to translate museum governance. These spokespeople include the provincial government, the OMA, and the OHS. They are themselves actor networks punctuated and represented through spokespeople (e.g., individual museum advisors, executive directors, presidents, and other representatives, including documents). As they translate museum governance, they have self-defined roles in assembling a museum policy in Ontario, and the provincial government has historically recognized them as spokespeople.

Poulard (2012) has shown that mediation between museum professionals shaped the state's role in museum governance in France. However, there is limited consideration of the museum community and their spokespeople within research on Canadian museum or cultural policy (e.g., Dorais, 1987; Gattinger \& Saint-Pierre, 2011) beyond graduate theses (e.g., Tivy, 2006). In order to learn from the spokespeople themselves, I conducted 27 semi-structured interviews with 28 spokespeople, plus 2 follow-up interviews. As spokespeople engage in translation, they produce texts. Texts are a means through which specific ontologies are constructed and performed while others are made invisible (Nimmo, 2011). These non-human entities function as intermediaries, passing between actors, thereby documenting moments of translation. As such, I also conducted a document analysis, examining actors' problematizations in text from the 1950 s to 2018 .

Importantly, the spokespeople consulted are also translators or, in the language of public policy literature, policy entrepreneurs (Kingdon, 1984) working to assemble a museum policy. Translators/spokespeople have multiple memberships. Research often assumes that entities are bounded-that is, they can be differentiated from other entities and from the environment in which they are situated. However, entities are not 
fixed, bounded, or certain (Woolgar, 1990). Translators have what Leigh Star (1991) terms multiple memberships and are enrolled in multiple worlds, drawing together practices mixed from these different worlds as they act. The spokespeople speak for the museum community and translate museum governance, but they are also members of the museum community with experience working in museums. Furthermore, the spokespeople identified are not distinctly bounded entities. For example, provincial museum advisors have historically worked with the associations, participating on boards and committees. This analysis, therefore, involves consideration of the overlapping and intersecting realities of spokespeople in Ontario museum governance.

\section{The Museum Community and its Governance: A History}

\subsection{Pre- Ontario Museum Association}

Prior to the establishment of museum associations in Canada, a provincial museum community did not exist as a punctuated actor. There were individual museums, but no spokespeople who actively constructed, enacted, and spoke for a community of museums via a shared narrative. For example, the 1932 Miers Report on Canadian museums noted a lack of co-operation amongst Canadian museums, recommending the establishment of national and/or regional museum associations (Miers \& Markham, 1932).

Provincially, the Ontario Historical Society formed a museums committee in 1953, aiming to "ascertain the needs and desires of the museums of the Province, to establish standards, to exchange ideas, to disseminate information, and to unite all in a fellowship of museum workers" (Taylor \& Taylor, 1968). The committee worked to unite museum workers and believed that standards were important to museums but did not yet perpetuate a narrative of a united community. Instead, its early newsletters highlighted the work of individual museums and discussed subjects of interest to museum workers (OHS Museum Section, 1953-1981).

Individuals from the OHS encouraged the province to fund museums, leading to a museum operating grant program for municipal museums in 1953 (Tivy, 2006). They also called for provincial museum advisors to provide museums with the technical assistance of a subject matter expert. The province created a museum advisor position in 1959 and expanded the section in the 1960s and 1970s to include additional advisors. Like the OHS committee, the new advisors' communications referred to individuals 
instead of a museum community. For example, in a 1959 OHS report on an annual workshop, the museum advisor mentioned the concerns of "museum people" and indicated a desire to be useful to "museum personnel" (Gooding, 1959).

In short, Ontario has had a provincial museum association since 1953 and provincial museum advisors since 1959. These translators focused on individual workers and museums. Beginning in the 1970s, a new editor wrote more extensive introductions and commentaries in the OHS's Newsletter, relying on a shared understanding of "we" (Gilbank, 1973, p. 195). The shift in language marked a shift toward an Ontario museum community.

\subsection{The Development of the Ontario Museum Association and Increased Advocacy}

The idea of a museum community became increasingly significant in the context of advocacy and policy development starting in the 1970s with the emergence of the Ontario Museum Association, which acted as the voice of the Ontario museum community (OMA, 1993). While the provincial museum advisors and Ontario Historical Society had worked to understand the needs of the museum community since the 1950s, the OMA provided a punctuated actor with the articulated responsibility of representing the community to government. Spokespeople then employed the term museum community as they translated a museum policy and enacted museum governance.

In 1971, museum workers met to form the OMA as a "group of individuals" with an interest in providing training for museum workers (OMA, 1972). Funding from the federal government's 1972 National Museum Policy allowed the OMA to establish and expand a training program. At the same time, the province provided the OMA with funding to study the issue of museum policy, supporting the OMA's belief that museum people needed to speak with a unified voice to be heard (McLauchlan, 1972).

The provincial museum advisors worked with the OMA, serving on the board and committees. Together, they began discussing the idea of a museum community as they advocated for changes to provincial museum governance. For example, in 1973 advisors wrote Suggested Programme for the Development of Local Museums in Ontario, emphasizing the museum community's potential acceptance of the proposals (Historical and Museums Branch, 1973). Based on their understanding of the community's issues, the suggestions led to a change in the museum grant, allowing nonprofit museums access, and the creation of a second office for museum advisors in Sault Ste. Marie, temporarily increasing the number of advisors from four to six. 
As part of broader reforms, the operating grant faced the threat of "deconditionalization" in 1974 and 1977-1978. Deconditionalization involved removing conditions on provincial grants in favour of a single, larger unconditional transfer from the province to municipalities to reduce the total number of grant programs and bureaucratic processes. The initiative would have eliminated operating grants to municipal museums. Understandably, "considerable opposition was expressed by the museum community" (OMA, 1977, p. 1). As the OMA met with provincial officials to advocate against deconditionalization, they renewed talks about a provincial museum policy that would include the existing operating grant and new standards of operation.

The provincial museum advisors developed a comprehensive policy document (1981) with associated standards (1984), consulting museums in community meetings and via the associations. The policy included the existing provincial advisory service, articulating a commitment to work with the associations as they offered community museums training. The operating grant became tied to standards that outlined a basic level of museum operations related to research, collection records management, staff training and professional development, exhibition, interpretation and educational programs, and conservation. The province created a new conservation program with conservators and a mobile lab to help museums meet the new requirements. Community museums were also encouraged to access existing provincial and federal project funding for culture, museums, and local projects.

Leading to and following the release of the policy and standards, the OMA and provincial museum advisors emphasized the museum community's support for the changes. Both argued that the standards were developed with the museum community after the community urged the province for criteria to serve as the basis for funding (Brent, 1984; OMA, 1984). The standards themselves stated that the Ontario museum commun-

ity "has long recognized and advocated the need for basic museological standards which all museums could strive to attain" (Heritage Branch, 1984, i).

\subsection{An Increased Role for the Ontario Museum Association and a Reduced Role for the Advisors}

During the 1990s, the Ontario Museum Association and museum advisors continued to promote the interests of the museum community as it experienced reduced financial support from all levels of government as part of broader cost-cutting measures. Since revising the standards, the province has gradually reduced the number of museum advisors and eliminated the conservator position. The OMA has, therefore, begun working more actively with the museum community to identify, address, and advocate for their needs. 
In 1998, the responsible minister sent a letter to museums indicating that the province would design a new support program in partnership with museums because the community voiced a need for updates to reflect contemporary practices and challenges (Bassett, 1998). Museum advisors then engaged in research on best practices and focus group consultations with selected representatives from the museum community, leading to revised standards in 2000. Despite the provincial narrative, the OMA's positions, as presented in its newsletter, Currently (1999-2000), did not portray the new standards as something called for by the museum community. A president's report noted, the "OMA is very concerned about the challenges of the Ministry asking museums to meet new standards and improve all services, at a time when the same Ministry continues to cut funding and resources to museums" (Havelka, 2000-2001, p. 5).

To help the museum community meet the new requirements, the OMA collaborated with museum advisors to provide training (Lalonde, 2005). They then successfully advocated for a 2.3 million dollar increase to the operating grant in 2007 and, following another increase in 2009, worked with advisors to make educational materials on the standards available online. While advisors have continued to work with the OMA, their capacity to provide advice and assistance has become limited. In the 1980s, there were three museum conservators and four museum advisors tasked to help museums meet standards. Now, there is only one.

In short, the provincial government and, therefore, the advisors have had a reduced role in the work of governing Ontario museums and defining the museum community while continuing to provide financial support. Conversely, the OMA has expanded its role. The OMA began a project in 2014 to define a strategy for Ontario's museum community, resulting in Ontario's Museums 2025: Strategic Vision and Action Plan (Looking Ahead Task Force, 2016). Following the new strategy, the OMA has pushed for an increase to the museum operating grant and developing resources themselves related to diversity and Indigenous issues. Considering the work to create Ontario's Museums 2025 and follow through on the objectives, the associations' representatives interviewed define the OMA's activities as more grassroots than provincial action. Due to their work, the museum community is now "ready to make a substantive and meaningful contribution" to government consultations (OMA, 2015).

\section{Translation Work}

The spokespeople-that is, museum advisors and Ontario Museum Association-who use the term "Ontario museum community" are also translators, engaging in translation to construct the museum community. While the Ontario Historical Society also engages 
in translation and was significant in the establishment of governing frameworks, its involvement in Ontario museum governance has become less prominent since the creation of the OMA. Within the second and third periods described, the OHS' translation work has focused more broadly on the heritage community.

Callon (1986a, 1986b) identifies four moments of translation: problematization, interessement, enrolment, and mobilization. These overlapping and interrelated moments are evident within spokespeople's translation work as they gather information, engage in dialogue, create new entities, and mobilize the museum community.

\subsection{Problematization: Information Gathering}

During problematization, actors attempt to (re)define actors' identities and goals (Callon, 1986a). Information gathering is, therefore, central to translators' work. In particular, museums and museum workers' self-defined needs, weaknesses, strengths, and historical development inform problematizations.

Translators have ongoing, direct relationships with museum workers and the museums that have enabled them to listen to a range of perspectives. For example, museum advisors conducted site visits as they provided advice and assistance. One advisor interviewed noted, traveling for site visits gave them "a really good grounding on what was going on in Ontario at the time." Site visits provided an understanding of the voice and concerns of museum operators - that is, their worries, aspirations, and funding issues. However, as shown above, funding for advisors to travel has become more limited and the number advisors was reduced to one. The associations, by contrast, have greater means to engage directly with museum workers. Past presidents interviewed noted the OMA continues to connect with members throughout the province, offering training and an annual conference. With the development of new communication technologies, the OMA also provides training and discussion forums digitally, which the secretariat can monitor to develop an understanding of the community. The translators, therefore, collect the voices of museums informally when they enact their roles by offering assistance or training.

As they advocate for change in governance, translators engage in work more actively, explicitly seeking information on museums and using their experiences to define the museum community. Translators will ask museums and museum workers to provide written feedback and complete surveys on given issues. For example, as part of the 1991 Community Museum Operating Grant application, museum advisors included a 
survey to understand museums' perspectives on the standards. The OMA conducted a similar survey in 1992, seeking perspectives on museum issues and their relationship with the province.

Consultation initiatives can involve community meetings and focus groups. For museum advisors, increased consultation occurred as they developed the museum standards in the 1980s, during a heritage policy review in the early 1990s, and as they revised the standards in 1999. The advisors engaged in community meetings in Spring 1980, November 1980, and Fall 1983 to understand museums' needs and perspectives on the new policy and standards. The OMA engages in increased consultation when they develop strategic plans for themselves or the sector and gather responses to government initiatives. For example, while developing Ontario's Museums 2025, the OMA engaged in stakeholder interviews, a roundtable discussion, and discussions with regional museum networks.

In short, information gathering is a key component to defining the museum community. An interviewed advisor, who worked from the 1980s to 2010s, observed that when translators do not actively engage with museums to define the community or its needs, they risk criticism. In addition to gathering information through ongoing relationships, translators, therefore, engage in special projects with feedback opportunities when (re) defining their own roles or advocating for changes in governance.

\subsection{Interessement: Dialogue}

During interessement, actors attempt to commit entities to proposed problematizations (Callon, 1986a), such as the definition of the associations' roles. To that end, dialogue is key to the translation of a museum community. Exchanges help define and function-

ally enact the community. As translators engage in ongoing processes of collecting and communicating information, they begin to define the opinions and concerns of the museum community. They then share ideas and develop a consensus as they communicate in a multi-directional manner.

Engaging in dialogue to negotiate actor identities often involves the creation of texts that are circulated to those perceived as part of the community. For example, prior to writing the standards, the advisors wrote guidelines for new museums entering the program, which served as a discussion point in regional meetings with museums and represented a particular vision of the Ontario museum community going forward. They defined the expected size and activities that museums should engage in to become part 
of the community. The Ontario Museum Association's consultations for their sectoral strategy also involved a discussion paper that outlined a vision of museums with meaningful collections relevant to contemporary society and contributing to the economy.

Translators generate additional written communications on the museum community that are circulated to museums and museum workers as part of ongoing roles and relationships. Most notably, they communicate their problematizations on the museum community through the associations' publications, which are then circulated to members. For example, the Canadian Museum Association's publication Muse had a special issue in 1992 on the state of the Canadian museum community. A former OMA executive director, an OMA past president, and a former intern with the museum advisors wrote an article for the issue, outlining a narrative about museums in Ontario and their relationship with the province. They highlighted the leadership role of the associations, which prodded the province to develop museum policy, and describe the standard's positive reception (Baeker, May, \& Tivy, 1992).

While written communication is easier to study due to its permanence, interpersonal relationships are also significant points of dialogue. For example, interviewed advisors who worked between the 1970s and the 1990s discussed the importance of a partner when they conducted site visits to museums. Through their conversations with each other, they were better able to understand the needs of the community. More broadly, translators participate in events as part of the museum community, engaging in dialogue with other museum workers at conferences and other events. For example, within the OMA's newsletter, Currently, Cathy Blackbourn (2007), who volunteered for the OMA committees and board then became the OMA's professional program manager and, eventually, a museum advisor, describes the OMA conferences, certificate courses, and volunteer opportunities as moments of exchange with colleagues.

In short, personal relationships involve dialogue between translators and museum representatives. On a broader scale, the consultative processes described most often involve creating draft documents after initial consultations. The different forms of dialogue allow for iterative processes of consultation to negotiate the definition of the museum community.

\subsection{Enrolment: Building Black Boxes and Obligatory Passage Points}

Enrolment includes strategies to impose definitions and establish interrelations amongst actors (Callon, 1986a). Translators enroll problematizations through the creation of obligatory passage points, thereby black-boxing interrelationships. Within Ontario 
museum governance, the problematization of a museum community needing and wanting provincially enforced standards of operations is reinforced through obligatory passage points to grants and circulation of resources related to the standards.

Museum advisors, past presidents, and executive directors interviewed who worked in their roles during the 1980s defined the standards as responding to a need long recognized and advocated for by the museum community. A team of provincial museum advisors and conservators wrote the standards based on their knowledge of museum concerns and internal communications. Feedback from the museum community informed revisions. The standards, therefore, represent an agreement from the museum community about the basic level of operations acceptable for individual museums, appropriate areas for provincial regulation, and a museum's objectives.

Because museums seeking funding had to meet the standards, the associations' training programs for museums began further reflecting the museum community's understanding of basic museum operations. In a 1991 survey on the museum standards, a respondent noted that they were "a 'child' of these standards, having been introduced and indoctrinated during the Certificate of Museum Studies seminars" (Community Museum, 1991). The OMA launched its Certificate in Basic Museum Studies in January 1980 prior to the launch of the provincial museum policy and standards. The certificate became the Certificate in Museum Studies (CMS) and underwent changes in the 1980s. The associated courses reflect and respond to the standards. For example, on a flyer titled "Looking for Resources to meet the 2005 Community Museum Standards?" the OMA lists four CMS courses, making direct connections between courses and standards (OMA, n.d.). Even those not in the grant program are thus encouraged to engage with the obligatory passage point attached to the grant.

\subsection{Mobilization: Defining the Work of Governing}

During mobilization, the actor network speaks with one voice. As already noted, the service organizations and advisors act as spokespeople for the museum community. When mobilized, the community has a shared narrative, such as an idea of growing professionalism or declining support. Evolving needs emerge from the shared narrative, which in turn shapes the work of those governing and speaking for museums. Interpretations of the museum community informs the translators' roles and the scope of their work in community museum governance, guiding prioritization of particular activities. Conceptions of the community also inform proposed definitions for other actor roles when spokespeople advocate, helping assemble relationships that support museums. 
As translators work to promote the interests of the museum community, their programs target the museum community and aim to build skills assessed as absent or underdeveloped (e.g., OMA, 2008). For example, the OMA has provided seminars and published resources, such as newsletters or directories. These resources highlight issues of interest to the museum community, including student employment programs, agreements with municipalities, and resolutions on charitable donations. Museum advisors have similarly developed resources based on their understandings of the museum community and its needs, including notes on museum operations that aimed to address areas of weakness (e.g., Citizenship and Culture, 1985).

The museum community is mobilized in advocacy. While advocating for the standards, translators argued that the museum community needed and wanted the standards because it had grown since the grant began (Styrmo, 1978) and had a growing conviction that provincial funding should be distributed differently (Museum Advisors, 1980). The OMA mobilizes the idea of a museum community and its support for the OMA's positions more broadly as the association pushes for government action. For example, the OMA argued against the deconditionalization of museum funding based on the museum community's understood preferences.

As translation is ongoing, mobilization of the museum community is also ongoing and seeks to generate consensus on past action. For example, the spokespeople advocated for standards, sought consensus from the museum community on those standards, and then continued to engage in a translation of that community. Following the release of the museum policy in 1981, a museum advisor noted that they held community meetings when developing the museum policy "to give individuals from the museum community a chance to express their concerns" (Duncan 1981, p. 4). The consulted museums expressed their priorities "almost unanimously," reinforcing the idea of a united community.

\section{Discussion}

The museum community only exists when spokespeople engage in translation and speak for the community in their own language. Despite translators' work to assemble information on museums broadly, voices are necessarily silenced to create consensus. During translation, translators' multiple memberships give particular museums greater capacity to define the museum community and its needs, (re)creating a hierarchy of museums as seen in the evolution of museum governance elsewhere (Poulard 2012). 
Existing research that focuses on large state institutions in Canada, such as the Royal Ontario Museum or the Canadian Museum of History (e.g., Jenkins, 2005; Aronczyk \& Brady, 2015), demonstrates a preoccupation in policy on museums receiving funding as Crown corporations or agencies. Studying community museum governance and the museum community highlights additional differentiation in museums' relationships with government due, in part, to the role that associations play in museum governance. The role of associations is changing as Ontario withdraws from more direct forms of governance through advice and assistance, thereby contributing to a shift in the Ontario Museum Association's translation work.

\subsection{The Historic Privileging of Municipal Museums}

As noted above, community museums in Ontario include both nonprofit and municipal museums. There are over 500 museums, art galleries, and historic sites in Ontario with different budgets and types of support. However, translators often have or have had membership in comparatively well-resourced museums, which are municipal or quasi-municipal actors. In addition to receiving a more secure source of municipal funding, they receive a range of no-cost services, such as information technology and human resources (Ontario Museums Association and Hill Strategies Research Inc., 2016).

These comparatively well-resourced museums are disproportionately represented in early mobilizations of the museum community. In the 1970s, participation on the OMA council and committees involved a prohibitive time commitment for the volunteers running small museums. For example, in 1972 the OMA president indicated executive meetings would rarely be held on weekends. In response, a member put forth a motion to hold meetings on the weekend because volunteers had regular jobs during the week. When council considered the motion, it realized council members had to be employed at a museum, making volunteer workers ineligible. ${ }^{2}$

While smaller museums could contribute to the discussion through consultation efforts, active members had more opportunities to shape the association's construction of the museum community through internal dialogue and the mobilization of community to government through advocacy. For example, one director of a municipal museum served on the OMA council while the OMA advocated for a policy and standards. He then attended meetings with the ministry to advocate for the standards, wrote letters to the minister on behalf of the OMA, and wrote letters as a museum director advocating for the enunciation of a rationale to help the museum community fight for the

2. The correspondence on this issue is available in: F2091 6 B253002 correspondence - council - president July 13, 1971 - Aug 26, 1975, Archives of Ontario, Toronto. 
grant. ${ }^{3}$ An interviewee who worked as an advisor during the 1960 s and 1970 s remembered representatives from larger museums as the ones pushing for standards, rather than coming from the museum community more broadly.

Letters to advisors from individual museums or museum workers opposing the standards were from those fearing they would be unable to meet the new standards (i.e., those without the support of their municipality). For example, one museum would have been unable to meet the size requirements in the 1980s version of the guidelines, as the museum "would have to be the largest building in [their] community." ${ }^{4}$ The museum's board chairman then wrote the ministry to oppose the policy, indicating that he had conducted independent research that showed a majority of the museum community did not favour the recommendations. Protesting the rigidity of the standards, another museum wrote that "small rural establishments like ours cannot comply."

Historical house museums, in particular, had reservations about the standards, expressing those concerns in an OMA survey prior to the release of the finalized standards. Respondents from small and historic site museums argued that they would be unable to meet the standards and would become ineligible for funding. They called for flexibility and a recognition of the constraints imposed on the dedicated volunteers running museums. While the OMA forwarded these comments and pushed for flexibility, it also minimized the findings, noting a silent majority supported the new museum policy because those who disagreed responded more often. ${ }^{5}$ The smaller museums' participation in consultation efforts was, therefore, undermined by their limited capacity to engage in ongoing dialogue and mobilization of their voices.

Considering the advisors' multiple memberships, their constructions of the museum community often reflected those seen in the associations. However, they engaged in their own translation work, actively consulting with smaller museums as they traveled the province, holding community meetings with small museums and providing technical advice to those who needed it most. As such, their conceptions of the museum community and its needs were not always the same as the museum community that the OMA discussed. For example, during the standards consultations in the 1980s, the OMA argued that the museum community would benefit from a requirement in the

3. See, for example, correspondence from the 1970s available in: RG47-50 B101703 manila envelope, Archives of Ontario, Toronto.

4. References to museum correspondence from the late 1970s and early 1980s in this section are available in: RG47-51 B183638, Archives of Ontario, Toronto.

5. Survey results and correspondence on the 1984 surveys are available in: RG47-50_i Ontario Museum Association vol iv. Archives of Ontario, Toronto. 
provincial standards that a curator have particular training. After consulting directly with the museum community, the advisors responded to smaller museums' articulation of their needs, changing the standards and removing the specific training requirement (Tivy, 2006).

Despite translators' work to engage a range of museums, the construction of a museum community by the well-resourced museums has shaped the development of articulated policies. In the 1970s and 1980s, the OMA argued for change or consistency on behalf of the museum community, which privileged museums already receiving the provincial operating grant. For example, during discussions on the standards, the ministry responsible for museums eliminated the only capital program specific to museums. The OMA did not publicly counter the minister's argument that the grant elimination was a positive because the number of new museums becoming eligible for funding would level out, avoiding the problem of "too many mouths to feed" (Baetz, 1980, p. 1).

\subsection{Changing Roles}

Notably, relationships between actors shift over time and, as a result, the power relations defined and enacted through translation also change. In particular, there has been a gradual reduction of advisors' capacity. While they continue to work for the museum community, they are not able to engage in the same problematization work as seen from 1959 to the 1990s. In 1981, as advisors began introducing standards, there was a conservation coordinator and two conservators. The museum section had its own manager with museum expertise who worked with a team of advisors. Today, there is only one advisor who is, for the most part, unable to conduct site visits or provide the same level of advisory services. As such, there is limited ability to engage in personal relationships and dialogue to define a museum community guided by the voices of smaller, non-municipal museums.

At the same time, the OMA has engaged in increased efforts to better represent museums in their diversity. Members have more opportunities to inform the OMA's direction and, as such, engage in the problematization of the community. For example, in 1986, the OMA conducted in its first strategic planning exercise. It began with a strategic planning retreat that included council members, staff, hired facilitators, and select members. The OMA then held 22 regional meetings where the strategic planning was one of three agenda items. Only two days after the final meeting, the council developed a statement of the roles and objectives to guide the OMA's policy and programming decision-making. In contrast, the Towards 2025: The Ontario Museum Association's 
Strategic Plan 2016-2021, built on Ontario's Museums 2025, involving institutional surveys, an additional sectoral survey, stakeholder interviews, a roundtable discussion at the OMA conference, discussions with regional networks and funders, a discussion paper, webinars, and social media engagement.

Following the Ontario's Museums 2025 work, the operating grant remains a major element in OMA advocacy. However, it is clearly articulated as a "first step" rather than the goal itself. A key component of the OMA's advocacy has become raising the profile of museum community broadly, educating the public and governments. Its training and resource creation for museums has moved well beyond provincial standards, which have been relatively static since 2000. For instance, the OMA's website includes resources and best practices related to inclusion and diversity, which are not part of provincial standards. The association has engaged in research in these areas, offered training, and sought funding for special projects.

\section{Conclusion}

Paquette and Redealli (2015) argue for additional research on cultural service organizations because "their role is so critical in bringing the actors in the field together and providing the knowledge required" (p. 125). Within Ontario, these organizations have also had a critical role in defining a museum community that has shaped museum governance in Ontario. The historical privileging of municipal museums' problematizations contributed to provincial policies that favour those municipal museums with greater capacity. As provincial museum advisors play a reduced role in museum governance, the Ontario Museum Association is more actively engaging in efforts to give voice to a broader cross section of museums. Their changing practices demonstrate a potential shift in power relationships in the province.

As a non-profit, the OMA does not have the capacity and is not given funding to employ advisors to provide the assistance the province once provided. As such, the advisors' translation work is lost. For example, information is no longer collected from visiting museums, which once provided valuable insights on the state of the smallest community museums in Ontario. Although the OMA is working to listen and respond to the voices of its members, the capacity of small non-profit museums is limited. Municipal or other government museums continue to have greater capacity to respond to consultations and speak than their non-profit counterparts. For example, between 1998 and 2018, the OMA had eleven presidents, but only two were from non-profit museums. 
The loss of advisors with the capacity to assemble voices without a corresponding increase in OMA funding to do the same risks further compounding a hierarchy of museums. Museums with limited capacity to speak for themselves are spoken for as part of the museum community, but the museum community can only include their voices so long as they can both speak and be heard. Additional research is needed as governments rely on the work of associations in museum governance to understand the role of existing and resulting power dynamics.

\section{References}

Aronzyk, M., \& Brady, M. (2015). Branding history at the Canadian Museum of Civilization. Canadian Journal of Communication, 40(2), 165-184.

Ashley, S. L. T. (2014). Engage the world: Examining conflicts of engagement in public museums. Internation Journal of Cultural Policy, 20(3), 261-280.

Baeker, G., May, M., \& Tivy, M. (1992). Ontario museums in the 1990s. Muse, 10(2-3), 120-123.

Baetz, R. (1980). Baetz announces future direction. Currently, 3(6), 1-2.

Bandelli, A., \& Konijn, E. A. (2015). Public participation and scientific citizenship in the science museum in London: Visitors' perceptions of the museum as a broker. Visitor Studies, 18(2), $131-149$.

Bassett, I. (1998). [Letter]. Operating grants case files for community museums. (RG47-41 B932597 CMOG 1999-00). Archives of Ontario, Toronto.

Blackbourn, C. (2007). Landscapes. Currently, Special $35^{\text {th }}$ anniversary print edition, 5.

Brent, M. (1984). An introduction to the standards for community museums in Ontario. Museum Quarterly, 13(3), 7-8.

Callon, M. (1986a). Some elements of a sociology of translation. In J. Law (Ed.), Power, action and belief. A new sociology of knowledge? (pp. 196-223). London: Routledge.

Callon, M. (1986b). The sociology of an actor-network: The case of the electric vehicle. In M. Callon, J. Law, \& A. Rip (Eds.), Mapping the dynamics of science and technology (pp. 19-34). London: Palgrave MacMillan.

Callon, M. (1991). Techno-economic networks and irreversibility. In J. Law (Ed.), A sociology of monsters: Essays on power, technology and domination (pp. 132-61). New York: Routledge.

Callon, M., \& Latour, B. (1981). Unscrewing the big leviathan: How actors macro-structure reality and how sociologists help them to do so. In K. Knorr Cetina \& A.V. Cicourel (Eds.), Advances in social theory and methodology: Toward an integration of micro and macro-sociologies (pp. 277-303). New York: Routledge.

Canadian Museum Association. (2016). The state of museums in Canada: Brief to the Standing Committee on Canadian Heritage. Ottawa: Canadian Museum Association. 
Citizenship and Culture, Government of Ontario. (1985). Ontario museum notes: Practical information on operating a community museum. Museum Notes, 1.

Heritage Branch, Ministry of Culture and Communications, Government of Ontario. (1984). Standards for Community Museums in Ontario. Operating grants case files for community museums. (RG47-41 B412703 operating grants 1989 procedures). Archives of Ontario, Toronto.

Clarke, J. (2012). The work of governing. In K. Coulter \& W. R. Schumann (Eds.), Governing cultures: Anthropological perspectives on political labor, power, and Government (pp. 209-231). New York: Palgrave Macmillan.

Community Museum. (1991). CMOG application form. Operating grants case files for community museums. (RG47-41 B340871). Archives of Ontario, Toronto.

Dorais, L. A. (1987). Musées nationaux du Canada: Une politique concrète. Loisir et Société, 1O(1), 69-82.

Duncan, D. (1981, October 17). Presentation at the annual workshop. Museum Section Correspondence. (RG47-51 B101695). Archives of Ontario, Toronto.

Gattinger, M., \& Saint-Pierre, D. (2011). Les politiques culturelles provinciales et territoriales du Canada. Origines, évolutions et mises en ouvre. Québec: PUL.

Gilbank, R. (1973). Newsletter, 143.

Gooding, S. J. (1959). The work of provincial museum advisors. In Ontario Historical Society Museums Section Workshop Report (pp.7-10). Toronto: Ontario Historical Society.

Gray, C. (2015). The politics of museums. Basingstoke: Palgrave MacMillan.

Greffe, X. (2011). The economic impact of the Louvre. The Journal of Arts Management, Law, and Society, 41(2), 121-137.

Havelka, M. (2000-2001). Currently, 23(4), 5-7.

Historical and Museums Branch, Government of Ontario. (1973). Suggested programme for the development of local Museums in Ontario. Museum Policy Development Reports. (RG47-79). Archives of Ontario, Toronto.

Jaffry, S., \& Apostolakis, A. (2011). Evaluating individual preferences for the British Museum. Journal of Cultural Economics, 35(1), 49-75.

Jenkins, B. (2005). Toronto's cultural renaissance. Canadian Journal of Communication, 30(2): $169-86$.

Jung, Y. (2015). Diversity matters: Theoretical understanding of and suggestions for the current fundraising practices of nonprofit art museums. Journal of Arts Management Law and Society, 45(4), 255-268.

Kingdon, J. (1984). Agendas, alternatives, and public policies. Boston: Little, Brown.

Lalonde, M. (2005, June 9). Letter to Ms. Oxley. Operating grants case files for community museums. (RG47-41 B931430 grants 2005-1DBC-2921 OMA). Archives of Ontario, Toronto. 
Latour, B. (2005). Reassembling the Social: An Introduction to Actor-Network-Theory. New York: Oxford University Press.

Law, J. (1992). Notes on the theory of the actor-network: Ordering, strategy, and heterogeneity. Systems Practice, 5(4), 379-393.

Leigh Star, S. (1990). Power, technology, and the phenomenology of conventions: On being allergic to onions. The Sociological Review, 38(S1), 26-56.

Looking Ahead Task Force. (2016). Ontario's museums 2025: Strategic vision E action plan. Toronto: Ontario Museum Association.

McCall, V. (2009). Social policy and cultural services: A study of Scottish border museums as implementers of social inclusion. Social Policy E Society, 8(3), 319-331.

McCann, E., \& Ward, K. (2013). A multi-disciplinary approach to policy transfer research: Geographies, assemblages, mobilities and mutations. Policy Studies, 34(1), 2-18.

McLauchlan, G. (1972, April 18). Letter to colleagues. Ontario Museum Association general correspondence files. (F2091 6 B253002 correspondence - council - president July 13,1971 - Aug 26, 1975). Archives of Ontario, Toronto.

Miers, S. H., \& Markham, S. F. (1932). A report on the museums of Canada. Edinburgh: T. and A. Constable.

Museum Advisors. (1980). Ontario's community museum programme directions for the 1980's: A discussion paper. Museum section correspondence. (RG47-51 B101712 policy papers I). Archives of Ontario, Toronto.

Nimmo, R. (2011). Actor-network theory and methodology: Social research in a more-than-human world. Methodological Innovations Online, 6(3), 108-119.

Nisbett, M. (2013). New perspectives on instrumentalism: an empirical study of cultural diplomacy. International Journal of Cultural Policy, 19(5), 557-575.

OHS Museum Section. (1953-1981). Newsletter.

OMA. (n.d.). [Flyer]. Museum section correspondence. (RG47-51 B929760 CSW05A-1 [OMA]). Archives of Ontario, Toronto.

OMA. (1972). Application for membership in the Ontario Museum Association: Explanatory notes. Museum section correspondence. (RG47-51 B328435). Archives of Ontario, Toronto.

OMA. (1977). Province to eliminate museum grants. Currently, 1(2), 1-2.

OMA. (1984). Community museum standards confirmed. Currently, 7(5), 1.

OMA. (1984). New wintario program grants. Currently, 7(6), 1.

OMA. 1993. Ontario Museum Association 1992-1993 Annual Report. Ontario Museum Association: Toronto.

OMA. (2000). OMA/AMO Annual Report 1999-2000. Ontario Museum Association: Toronto. 
OMA. (2008). Research into the sustainability of Ontario's community museums: CMOG snapshot 2000-2004. Retrieved April 21, 2020 from https://members.museumsontario.ca/sites/default/ files/members/CMOGsnapshot20002004.pdf

OMA. (2015, November 17). [Open Letter]. Retrieved April 21, 2020 from https://gallery.mailchimp. com/9a74d213d7e397025fc8b7b8e/files/11_17_15_OMA_Cult_consultation_submission_ FINAL_1_.pdf

Ontario Museums Association and Hill Strategies Research Inc. (2016). Ontario's museums 2014 profile highlights. Retrieved April 21, 2020 from https://members.museumsontario.ca/sites/default/files/ members/publications/ProfileHighlights_OnlineView2.pdf

Paquette, J. (2010). La réforme des musées nationaux du Canada: Défis professionnels et managériaux de la recherche. Canadian Public Administration, 53(3), 375-394.

Paquette, J., \& Redaelli, E. (2015). Arts management and cultural policy research. London: Palgrave MacMillan.

Parsons, M. D. (1999). The problem of power: Seeking a methodological solution. Policy Studies Review, 16(3), 279-310.

Poulard, F. (2012). Curators and the state, a question of interdependencies: The case of France. In J. Paquette (Ed.), Cultural Policy, Work and Identity. The Creation, Renewal and Negotiation of Professional Subjectivities (pp. 77-90). London: Routledge.

Rice, L. (2011). Black-boxing sustainability. Journal of Sustainable Development, 4(4), 32-36.

Stylianou-Lambert, T., Boukas, N., \& Christodoulou-Yerali, M. (2014). Museums and cultural sustainability: Stakeholders, forces, and cultural policies. International Journal of Cultural Policy, 20(5), 179-185.

Styrmo, V. (1978). [Memo]. Museum section correspondence. (RG47-51 B101712 unlabeled). Archives of Ontario, Toronto.

Taylor, A. W., \& Taylor, V. B. (1968). Our aim and basis. Newsletter, 118, 3.

Tivy, M. (2006). The local history museum in Ontario: An intellectual history. Waterloo, ON: University of Waterloo.

Weil, S. E. (1997). Museums in the United States: The paradox of privately governed public institutions. Museum Management and Curatorship, 15(3), 249-257.

Woolgar, S. (1990). Configuring the user: The case of usability trails. The Sociological Review, 38(S1), 58-99.

Zapata Campos, M. J., \& Zapata, P. (2013). Translating development aid into city management: The barrio acahualinca integrated development programme in Managua, Nicaragua. Public Administration and Development, 33(2), 101-112. 